\title{
EFFECT OF MULTI-NUTRIENTS APPLICATION ON THE YIELD AND QUALITY OF GRAPES VARIETY MUSCAT
}

\author{
Jegadeeswari $\mathrm{D}^{1^{*}}$, T. Chitdeshwari ${ }^{1}$, A.K. Shukla ${ }^{2}$ \\ ${ }^{1}$ Department of Soil Science and Agricultural Chemistry, Tamil Nadu Agricultural University, Coimbatore- 641003 \\ ${ }^{2}$ Indian Institute of Soil Science, Bhopal - 462038
}

Received - June 01, 2020; Revision - July 06, 2020; Accepted - July 29, 2020

Available Online - August 25, 2020

DOI: http://dx.doi.org/10.18006/2020.8(4).426.433

\section{KEYWORDS \\ Grapes \\ Secondary nutrients \\ Micronutrients \\ Growth parameters}

Yield

\begin{abstract}
A field experiment was conducted to assess the effect of soil and foliar application of secondary and micronutrients in the existing eight years old grapevine orchard (Muscat) located at Theethipalayam village of Coimbatore district with ten treatments and three replications under randomized block design revealed that soil and foliar application of $\mathrm{Ca}, \mathrm{Mg}$ and $\mathrm{Zn}, \mathrm{Fe}$, B with NPK increased the bunch yield of grapes from 12.5 to $16.4 \mathrm{t} \mathrm{ha}^{-1}$ with a mean of $14.5 \mathrm{t} \mathrm{ha}^{-1}$. Bunch weight ranged from 158 to $407 \mathrm{~g} \mathrm{bunch}^{-1}$ and the numbers of fruits varied from 60.7 to 145 per bunch with an average of 254 and 101 respectively. Higher bunch yield of $16.4 \mathrm{t} \mathrm{ha}^{-1}$, bunch weight of $407 \mathrm{~g} \mathrm{bunch}^{-1}$ and number of berries/bunch of 145 were recorded with the application of RDF (200: 160:1200 g/vine in two splits) $+25 \mathrm{~kg} \mathrm{ZnSO}_{4} 50 \mathrm{~kg} \mathrm{FeSO}_{4} 10$ $\mathrm{kg}$ borax along with foliar spraying of $0.5 \% \mathrm{CaNO}_{3}+0.5 \% \mathrm{MgSO}_{4} \quad 0.5 \% \mathrm{~K}_{2} \mathrm{SO}_{4}$ twice during flowering and early berry formation stage. Higher juice content of $87 \%$ and TSS of 18.1 (Brixo) was also recorded in the same treatment. This was comparable with the same basal soil application of RDF micronutrients foliar spraying of $0.1 \%$ Boric acid $+0.2 \% \mathrm{ZnSO}_{4}+0.5 \% \mathrm{FeSO}_{4}$. The micronutrient concentrations in petiole and bulb were also increased considerably and the values for Fe were: 84.2 to $101.4 \mathrm{mg} \mathrm{kg}^{-1}$ and 66.5 to 78.9 $\mathrm{mg} \mathrm{kg}^{-1} \mathrm{Fe}$ in petiole and berry respectively and sustained the micronutrient availability in soil.
\end{abstract}

* Corresponding author

E-mail: jagadeeswari.d@tnau.ac.in (Jegadeeswari D)

Peer review under responsibility of Journal of Experimental Biology and Agricultural Sciences.

Production and Hosting by Horizon Publisher India [HPI] (http://www.horizonpublisherindia.in/).

All rights reserved.
All the articles published by Journal of Experimental Biology and Agricultural Sciences are licensed under a Creative Commons Attribution-NonCommercial 4.0 International License Based on a work at www.jebas.org.

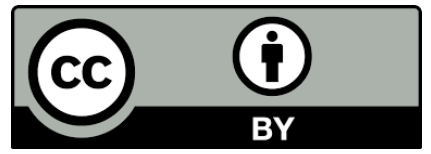




\section{Introduction}

Grape (Vitis vinifera L.) is an important commercial fruit crop of tropical and temperate regions. It is a good refreshing table fruit, rich in sugars, acid, and minerals like nitrogenous compounds, iron, calcium, magnesium. Grapes are also rich in vitamins B1, B2, C, and tannins (Swathi et al., 2019). Next to banana, it is preferably consumed by all people which leads to greater demand. Globally it is grown in an area of about 8.92 million hectares with an annual production of 64.9 million tonnes. Theni, Dindigul, Krishnagiri, and Coimbatore are the major grape growing districts in Tamil Nadu. In the grape orchard, water, soil health, and vine maintenance are the three major factors that decide the yield of the crop. Among these three, soil health is very important, hence nutrient removal has to be replenished adequately based on the demand of crop to get maximum berry yield. Soil fertility affects the yield and quality of berries (Bhat et al., 2017). Integrated nutrient management plays a crucial role in the production and quality of the grape. Earlier studies well supported the application of nutrients in increasing the yield and quality of grapes. During critical stages of the crop and at adverse soil conditions foliar application is one of the best methods to support the nutrients to the plant when compared to soil application alone (Souri \& Hatamian, 2019). Epibrassinolides foliar application improved the zinc and boron efficiency on increasing fruit set and grape yield per vine. Biochemical and reproductive characteristics as well as fruit set percentage was highly influenced by zinc sulfate $\left(2 \mathrm{~g} \mathrm{~L}^{-1}\right)$ and boric acid $\left(0.5 \mathrm{~g} \mathrm{~L}^{-1}\right)$ foliar application followed by Foliar spray of epibrassinolide $\left(\mathrm{mg} \mathrm{L}^{-1}\right)$. Boric acid spray@0.3\% positively influenced the cluster weight, width, volume, grape yield, and concentrations of nutrients like NPK, $\mathrm{Ca}, \mathrm{Mg}, \mathrm{Zn}$, and $\mathrm{Cu}$ in leaves (Bilir et al., 2018).
Hence a holistic nutrient management package is a vital key for every orchard system to obtain higher productivity, yield, and to sustain the soil health. Nutrient application at the critical stage of the crop will ensure good quality, higher yield, and health of the vine system as a whole. Foliar application is one of the best methods to substitute the nutrient demand particularly during critical stages of the crop. All parts for attaining normal physiological and biochemical functions demand an adequate supply of macro as well as micronutrients. With this background a field experiment was conducted at Theethipalayam village of Thondamuthur block, Coimbatore district to study the effect of foliar application of micro and secondary nutrients on the yield and quality of grapes.

\section{Materials and Methods}

\subsection{Experimental vineyard}

About 8-year-old grape vineyard grown with variety Muscat (panneer) was selected for the study and vines were planted in quincunx system, with a spacing of $4 \mathrm{mX} 3 \mathrm{~m}$. The field was located in the western zone of Tamil Nadu at $76^{\circ}$ 49' East longitude and $11^{0} 00^{\prime}$ North latitude at Theethipalayam village of Thondamuthur block, Coimbatore district, Tamil Nadu, India. The initial soil sample was collected from $0-15 \mathrm{~cm}$ depth and analyzed for various physicochemical characteristics (Table 1).

\subsection{Experimental design}

The experiment was conducted during the rabi 2017 vegetative season, ten treatments were imposed in a randomized block design with three replications comprising 4 vines in each replication (12 vines were maintained for each treatment). The treatment details were furnished below in Table 2 .

Table 1 Details of analytical procedures employed in soil and plant sample analysis

\begin{tabular}{|lll|}
\hline \multicolumn{1}{|c|}{ Parameters } & \multicolumn{1}{c|}{ Methodology } & Reference \\
\hline \multicolumn{1}{|c|}{ Physicochemical Properties } \\
\hline Soil reaction $(\mathrm{pH})$ & Potentiometry (1:2.5 soil: water suspension) & (Jackson, 2005) \\
\hline Electrical conductivity & Conductometry (1:2.5 soil: water suspension) & (Jackson, 2005) \\
\hline Free $\mathrm{CaCO}_{3}$ & Rapid titration method & (Piper, 1944) \\
\hline & \multicolumn{1}{c|}{ Chemical Properties } & \\
\hline Soil Organic Carbon & Chromic acid wet digestion method & (Walkley \& Black, 1934) \\
\hline Available Nitrogen $(\mathrm{N})$ & Alkaline permanganate method & (Subbiah \& Asija, 1956) \\
\hline Available Phosphorus (P) & Olsen method & Olsen et al. (1954) \\
\hline Available Potassium $(\mathrm{K})$ & Neutral N NH${ }_{4} \mathrm{OAC}$ & (Stanford \& English, 1949) \\
\hline Soil and plant: $\mathrm{Zn}, \mathrm{Cu}, \mathrm{Fe} \& \mathrm{Mn}$ & DTPA extraction AAS method & (Lindsay \& Norvell, 1978) \\
\hline
\end{tabular}

Journal of Experimental Biology and Agricultural Sciences

http://www.jebas.org 
Table 2 Detail of imposed treatments along with used concentrations

Treatments

RDF - Recommended dose of NPK@(200:160:1200 g/vine )

$25 \mathrm{~kg} \mathrm{ZnSO}_{4}+50 \mathrm{~kg} \mathrm{FeSO}_{4}+10 \mathrm{~kg}$ Borax

$0.1 \%$ Boric acid $+0.2 \% \mathrm{ZnSO}_{4}+1.0 \%$ Urea FS

$0.1 \%$ Boric acid $+0.2 \% \mathrm{ZnSO}_{4}+0.5 \% \mathrm{FeSO}_{4} \mathrm{FS}$

$1 \% \mathrm{DAP}+1 \%$ Urea $+0.5 \% \mathrm{~K}_{2} \mathrm{SO}_{4} \mathrm{FS}$

$0.5 \% \mathrm{CaNO}_{3}+0.5 \% \mathrm{MgSO}_{4}+0.5 \% \mathrm{~K}_{2} \mathrm{SO}_{4} \mathrm{FS}$

$0.1 \%$ Boric acid $+0.2 \% \mathrm{ZnSO}_{4}+0.5 \% \mathrm{FeSO}_{4} \& 1 \% \mathrm{DAP}+1 \%$ Urea $+0.5 \% \mathrm{~K}_{2} \mathrm{SO}_{4}, \mathrm{FS}$

$0.1 \%$ Boric acid $+0.2 \% \mathrm{ZnSO}_{4}+0.5 \% \mathrm{FeSO}_{4}+0.5 \% \mathrm{CaNO}_{3}+0.5 \% \mathrm{MgSO}_{4}+0.5 \% \mathrm{~K}_{2} \mathrm{SO}_{4} \mathrm{FS}$

$25 \mathrm{~kg} \mathrm{ZnSO}_{4}+50 \mathrm{~kg} \mathrm{FeSO}_{4}+10 \mathrm{~kg}$ borax $+0.1 \%$ Boric acid $+0.2 \% \mathrm{ZnSO}_{4}+0.5 \% \mathrm{FeSO}_{4} \mathrm{FS}$

$25 \mathrm{~kg} \mathrm{ZnSO}_{4}+50 \mathrm{~kg} \mathrm{FeSO}_{4}+10 \mathrm{~kg}$ borax $+0.5 \% \mathrm{CaNO}_{3}+0.5 \% \mathrm{MgSO}_{4}+0.5 \% \mathrm{~K}_{2} \mathrm{SO}_{4} \mathrm{FS}$

*FS - Foliar spray during flowering and early berry formation stage RDF is common to all the treatments

Secondary nutrients calcium, magnesium, and micronutrients were applied as foliar sprays twice during flowering and at the early berry formation stage as per the treatment schedule in the morning hours. Manual weed control was practiced and pests and disease control measurements were taken up regularly as and when needed. Secondary and micronutrients were applied as foliar sprays twice during flowering and at the early berry formation stage as per the treatment schedule in the morning hours. Manual weed control was practiced and pests and disease control measurements were taken up regularly as and when needed.

\subsection{Yield and quality parameters}

The ripened bunches were harvested from each treatment separately and the number of bunches per vine and bunch weight per vine was recorded. Cluster weight was determined and expressed in grams. Cluster length $(\mathrm{cm})$ and width $(\mathrm{cm})$ were measured with a ruler by using thread. The total soluble solids content of the extracted juice was determined by using an Erma hand refractometer $\left(0-32^{\circ} \mathrm{B}\right)$ and expressed as degree Brix (Ranganna, 1997).

\subsection{Statistical analysis}

The experimental data collected relating to different parameters were statistically analyzed using the procedure given by Panse \& Sukhatme (1967). The data were subjected to Fisher's method of analysis of variance and the level of significance used in the $\mathrm{F}$ test was $\mathrm{P}=0.05$. The critical difference was calculated at 5 percent probability level whenever the $\mathrm{F}$ value was found to be significant.

\section{Results and Discussion}

The experimental soil was sandy clay loam in texture, slightly calcareous, and shallow. The grape variety viz, Panneer (Muscat) was grown as test crop and various yield attributes like bunch weight, numbers of berries bunch ${ }^{-1}$ and bunch yield was recorded and reported. Besides, soil and plant samples were collected at the post-harvest stage and analyzed for various micronutrients. The experimental soil was slightly alkaline in $\mathrm{pH}(8.30)$ and free from salinity with an electrical conductivity of $0.20 \mathrm{dS} \mathrm{m}^{-1}$. The organic carbon content was medium with low available $\mathrm{N}$ status $(232 \mathrm{~kg} \mathrm{~N}$ $\left.\mathrm{ha}^{-1}\right)$, medium available $\mathrm{P}\left(20.1 \mathrm{~kg} \mathrm{P} \mathrm{ha}^{-1}\right)$, and high in $\mathrm{K}\left(618 \mathrm{~kg} \mathrm{ha}^{-1}\right)$ and $\mathrm{S}\left(21.6 \mathrm{~kg} \mathrm{ha}^{-1}\right)$. The soil was deficient in DTPA Fe (4.12 $\left.\mathrm{mg} \mathrm{kg}^{-1}\right)$ while the status of other micronutrients was sufficient (Table 3 ).

Table 3 Initial soil characteristics of experimental field

Characteristics Values

$\mathrm{pH}$

\begin{tabular}{|lc|}
\hline Electrical conductivity $\left(\mathrm{dS} \mathrm{m}^{-1}\right)$ & 0.20 \\
\hline Organic carbon $\left(\mathrm{g} \mathrm{kg}^{-1}\right)$ & 6.52 \\
\hline $\begin{array}{c}\text { Available Nutrients }\left(\mathrm{kg} \mathrm{ha}^{-1}\right) \\
\text { Nitrogen }\end{array}$ & 232 \\
\hline Phosphorus & 20.1 \\
\hline Potassium & 616 \\
\hline Sulphur & 21.6 \\
\hline $\begin{array}{c}\text { DTPA Micronutrients }\left(\mathrm{mg} \mathrm{kg}^{-1}\right) \\
\text { Zinc }\end{array}$ & 1.08 \\
\hline Iron & 4.12 \\
\hline Copper & 5.41 \\
\hline Manganese & 11.2 \\
\hline
\end{tabular}




\subsection{Grape yield}

The bunch yield of grapes ranged from 12.5 to $16.4 \mathrm{t} \mathrm{ha}^{-1}$ with a mean of $14.5 \mathrm{tha}^{-1}$. Among the treatments, higher bunch yield of $16.4 \mathrm{t} \mathrm{ha}^{-1}$ was recorded with the combined soil application of $\mathrm{RDF}+25 \mathrm{~kg} \mathrm{ZnSO}_{4}+50 \mathrm{~kg} \mathrm{FeSO}_{4}+10 \mathrm{~kg}$ borax and foliar spraying of $0.5 \% \mathrm{CaNO}_{3}+0.5 \% \mathrm{MgSO}_{4}+0.5 \% \mathrm{~K}_{2} \mathrm{SO}_{4}$ twice during flowering and early berry formation stage which was comparable with the same basal soil application of $\mathrm{RDF}+$ micronutrients + foliar spraying of $0.1 \%$ Boric acid $+0.2 \% \mathrm{ZnSO}_{4}+0.5 \% \mathrm{FeSO}_{4}$ (Table 3). This indicated that soil application along with foliar spraying of micronutrients was found effective in increasing the grape yield and yield attributes. Foliar application of micronutrients had been associated with an improved number of clusters, average cluster weight, and the quality of vines (Akbar et al., 2013; Abo Ahmedeh et al., 2020). The lowest bunch yield $\left(12.5 \mathrm{t} \mathrm{ha}^{-1}\right)$ was recorded in the treatment that received RDF alone. The yield increase was $31.2 \%$ for the basal combined application of $\mathrm{RDF}+25 \mathrm{~kg} \mathrm{ZnSO}+50 \mathrm{~kg} \mathrm{FeSO}+10 \mathrm{~kg}$ borax + foliar spraying of $0.5 \% \mathrm{CaNO}_{3}+0.5 \% \mathrm{MgSO}_{4}+0.5 \% \mathrm{~K}_{2} \mathrm{SO}_{4}$.

\subsection{Yield attributes}

Bunch weight ranged from 158 to $407 \mathrm{~g} \mathrm{bunch}^{-1}$ and the number of fruits varied from 60.7 to 145 per bunch with an average of 254 and $101 \mathrm{~g}$ respectively. Among the treatments, higher bunch weight of $407 \mathrm{~g} \mathrm{bunch}^{-1}$ and number of berries/bunch of $145 \mathrm{~g}$ per bunch were recorded with the combined soil application of RDF+ $25 \mathrm{~kg}$ $\mathrm{ZnSO}_{4}+50 \mathrm{~kg} \mathrm{FeSO}+10 \mathrm{~kg}$ borax and foliar spraying of $0.5 \%$ $\mathrm{CaNO}_{3}+0.5 \% \mathrm{MgSO}_{4}+0.5 \% \mathrm{~K}_{2} \mathrm{SO}_{4}$ twice during flowering and early berry formation stage which was comparable with the same basal soil application of $\mathrm{RDF}+$ micronutrients + foliar spraying of $0.1 \%$ Boric acid $+0.2 \% \mathrm{ZnSO}_{4}+0.5 \% \mathrm{FeSO}_{4}$ (Figure $1 \& 2$ ).

The results indicated that soil application along with foliar spraying of micronutrients was found effective in increasing the grape yield and yield attributes of gapes. Increased cluster weight which sprayed with $\mathrm{B}$ and $\mathrm{Zn}$ could be attributed to increased berry set, numbers of berry in a cluster, and size of berry (Ebadi et al., 2001). The lowest bunch weight (158 g bunch $^{-1}$ ) and numbers of berries/bunch (60.7 per bunch) were recorded in the treatment that received RDF alone. All parts for attaining normal physiological and biochemical functions demand an adequate supply of macro as well as micronutrients. Besides basic nutrients (NPK), other elements like Calcium, Magnesium, Iron, Zinc and boron are considered to be essential for grapevine metabolism, growth processes, fruit set as well as berry development, because they are co-factors and activators of many metabolic processes (Ashley, 2011).

\subsection{Quality attributes}

Quality parameters like juice content (\%) and TSS (Brix $\left.{ }^{\circ}\right)$ were recorded and the results varied from 83.1 to $87 \%$ and 16.3 to

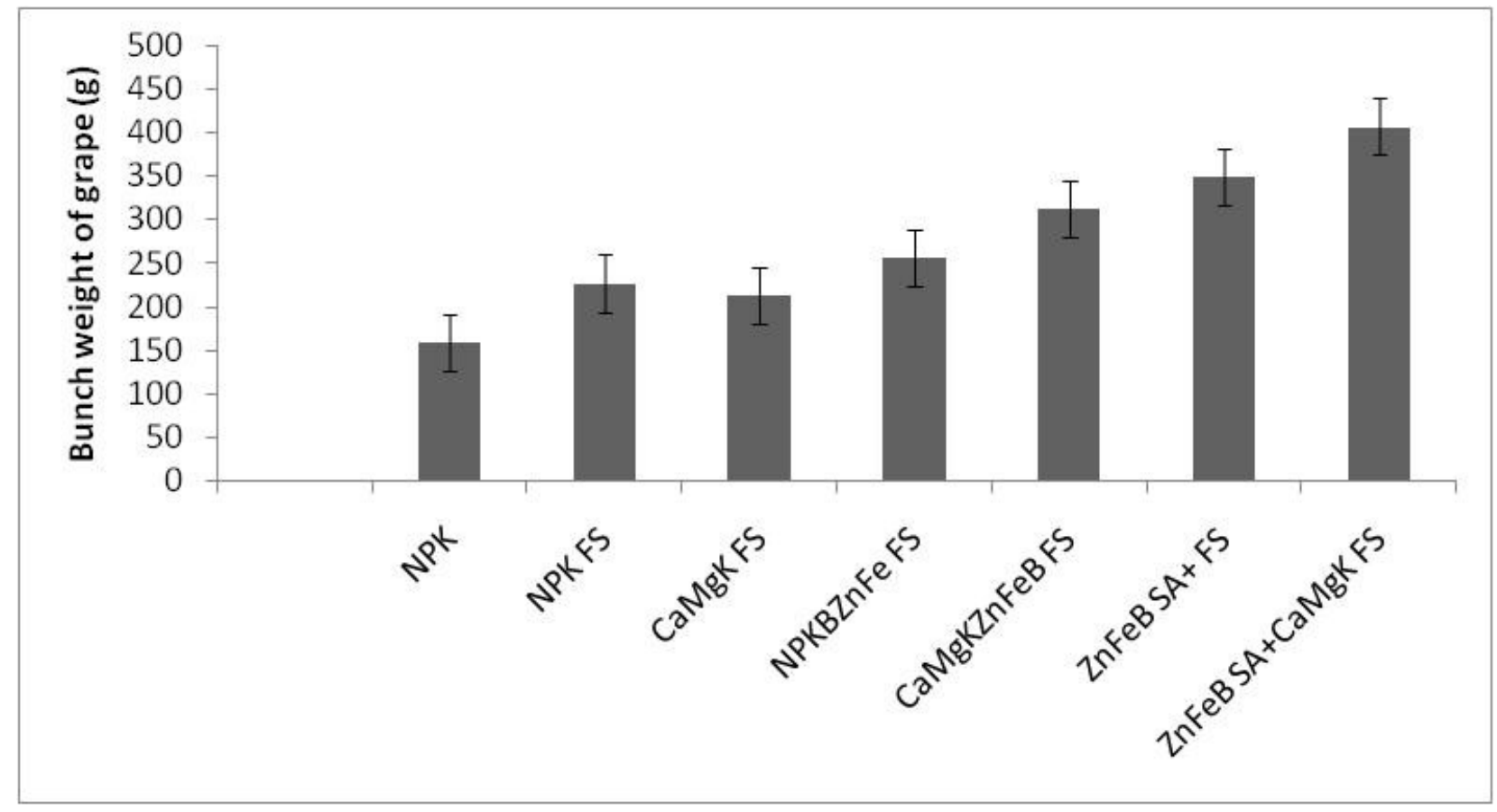

Figure 1 Effect of foliar application of nutrients on the bunch weight of grapes

Journal of Experimental Biology and Agricultural Sciences http://www.jebas.org 


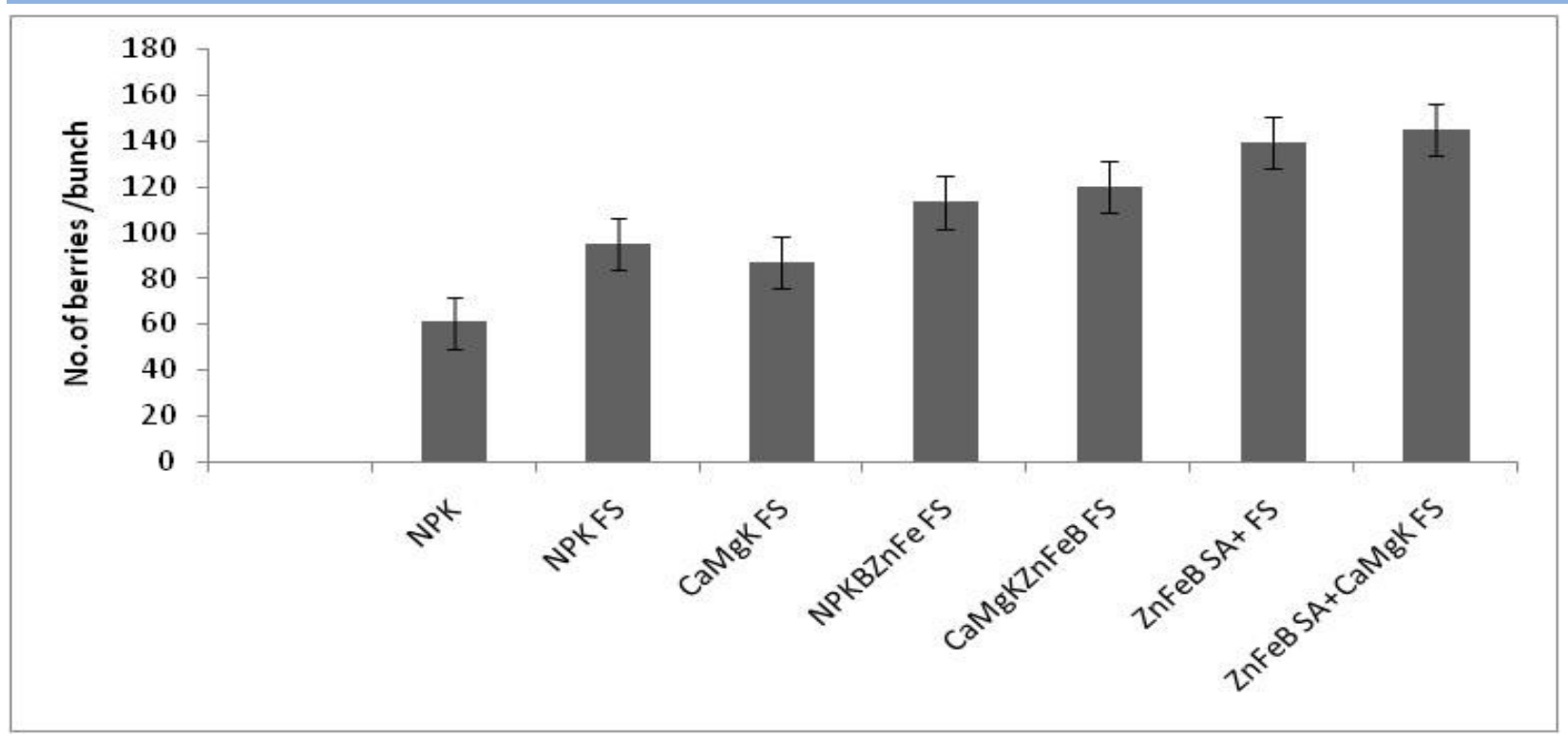

Figure 2 Effect of foliar application of nutrients on number of berries per bunch

Table 4 Effect of multi- nutrients application on the quality parameters of grapes

\begin{tabular}{|c|c|c|c|}
\hline Treatment details & Grape yield $\left(\mathrm{t} \mathrm{ha}^{-1}\right)$ & Juice content $(\%)$ & $\operatorname{TSS}\left(\right.$ Brix $\left.^{\circ}\right)$ \\
\hline Recommended NPK(RDF) & 12.5 & 83.1 & 16.3 \\
\hline $25 \mathrm{~kg} \mathrm{ZnSO}_{4}+50 \mathrm{~kg} \mathrm{FeSO}_{4}+10 \mathrm{~kg}$ borax & 14.6 & 85.0 & 17.4 \\
\hline $0.1 \%$ Boric acid $+0.2 \% \mathrm{ZnSO}_{4}+1.0 \%$ Urea FS & 13.5 & 83.8 & 16.7 \\
\hline $0.1 \%$ Boric acid $+0.2 \% \mathrm{ZnSO}_{4}+0.5 \% \mathrm{FeSO}_{4} \mathrm{FS}$ & 13.1 & 84.0 & 16.9 \\
\hline $1 \% \mathrm{DAP}+1 \%$ Urea $+0.5 \% \mathrm{~K}_{2} \mathrm{SO}_{4} \mathrm{FS}$ & 14.2 & 84.3 & 17.1 \\
\hline $0.5 \% \mathrm{CaNO}_{3}+0.5 \% \mathrm{MgSO}_{4}+0.5 \% \mathrm{~K}_{2} \mathrm{SO}_{4} \mathrm{FS}$ & 13.9 & 85.3 & 17.6 \\
\hline $\begin{array}{l}0.1 \% \text { Boric acid }+0.2 \% \mathrm{ZnSO}_{4}+0.5 \% \mathrm{FeSO}_{4+} \\
1 \% \text { DAP }+1 \% \text { Urea }+0.5 \% \mathrm{~K}_{2} \mathrm{SO}_{4} \mathrm{FS}\end{array}$ & 14.9 & 86.0 & 17.8 \\
\hline $\begin{array}{l}0.1 \% \text { Boric acid }+0.2 \% \mathrm{ZnSO}_{4}+0.5 \% \mathrm{FeSO}_{4}+ \\
0.5 \% \mathrm{CaNO}_{3}+0.5 \% \mathrm{MgSO}_{4}+0.5 \% \mathrm{~K}_{2} \mathrm{SO}_{4} \mathrm{FS}\end{array}$ & 15.4 & 86.6 & 18.0 \\
\hline $\begin{array}{l}25 \mathrm{~kg} \mathrm{ZnSO}_{4}+50 \mathrm{~kg} \mathrm{FeSO}_{4}+10 \mathrm{~kg} \text { borax }+ \\
0.1 \% \text { Boric acid }+0.2 \% \mathrm{ZnSO}_{4}+0.5 \% \mathrm{FeSO}_{4} \mathrm{FS}\end{array}$ & 16.1 & 87.0 & 18.1 \\
\hline $\begin{array}{l}25 \mathrm{~kg} \mathrm{ZnSO}_{4}+50 \mathrm{~kg} \mathrm{FeSO}_{4}+10 \mathrm{~kg} \text { borax }+ \\
0.5 \% \mathrm{CaNO}_{3}+0.5 \% \mathrm{MgSO}_{4}+0.5 \% \mathrm{~K}_{2} \mathrm{SO}_{4} \mathrm{FS}\end{array}$ & 16.4 & 84.9 & 17.5 \\
\hline SEd & 0.16 & 0.96 & 0.40 \\
\hline $\mathrm{CD}(\mathrm{P}=0.05)$ & 0.33 & 2.02 & 0.80 \\
\hline
\end{tabular}

* RDF is common to all the treatments

18.1(Brix $\left.{ }^{\circ}\right)$ respectively. Among the treatments, higher juice content of $87 \%$ and TSS of $18.1\left(\right.$ Brix $^{\circ}$ ) was recorded with the combined soil application of RDF+ $25 \mathrm{~kg} \mathrm{ZnSO}_{4}+50 \mathrm{~kg} \mathrm{FeSO}_{4}+10 \mathrm{~kg}$ borax and foliar spraying of $0.5 \% \mathrm{CaNO}_{3}+0.5 \% \mathrm{MgSO}_{4}+0.5 \% \mathrm{~K}_{2} \mathrm{SO}_{4}$ twice during flowering and early berry formation stage (Table 4). The lowest juice content $(83.1 \%)$ and TSS $\left(16.3 \mathrm{Brix}^{\circ}\right)$ was recorded in the treatment that received RDF alone. This differential response was due to the impact of different fertilization doses. In this study, the number of fruits per bunch, yield per vine and yield per hectare were increased with the combined soil application of RDF+ $25 \mathrm{~kg}$ $\mathrm{ZnSO}_{4}+50 \mathrm{~kg} \mathrm{FeSO}+10 \mathrm{~kg}$ borax and foliar spraying of $0.5 \%$ $\mathrm{CaNO}_{3}+0.5 \% \mathrm{MgSO}_{4}+0.5 \% \mathrm{~K}_{2} \mathrm{SO}_{4}$ twice during flowering and early berry formation stages. This might be due to the combined influence of secondary and micronutrients thereby increased photosynthetic activity, good shoot and reproductive growth finally resulted in more bunch weight and yield. 
Table 5 Effect of Effect of multi- nutrients application on the micronutrients contents $\left(\mathrm{mg} \mathrm{kg}^{-1}\right)$ in petiole

\begin{tabular}{|c|c|c|c|c|}
\hline \multirow{2}{*}{ Treatment details } & \multicolumn{4}{|c|}{ Petiole } \\
\hline & $\mathrm{Zn}$ & $\mathrm{Fe}$ & $\mathrm{Mn}$ & $\mathrm{Cu}$ \\
\hline Recommended NPK(RDF) & 71.1 & 84.2 & 66.8 & 21.1 \\
\hline $25 \mathrm{~kg} \mathrm{ZnSO}_{4}+50 \mathrm{~kg} \mathrm{FeSO}_{4}+10 \mathrm{~kg}$ borax & 81.4 & 94.6 & 79.3 & 26.8 \\
\hline $0.1 \%$ Boric acid $+0.2 \% \mathrm{ZnSO}_{4}+1.0 \%$ Urea FS & 72.4 & 89.3 & 68.9 & 22.8 \\
\hline $0.1 \%$ Boric acid $+0.2 \% \mathrm{ZnSO}_{4}+0.5 \% \mathrm{FeSO}_{4} \mathrm{FS}$ & 72.0 & 86.8 & 67.4 & 22.4 \\
\hline $1 \% \mathrm{DAP}+1 \%$ Urea $+0.5 \% \mathrm{~K}_{2} \mathrm{SO}_{4} \mathrm{FS}$ & 73.0 & 92.4 & 69.1 & 23.3 \\
\hline $0.5 \% \mathrm{CaNO}_{3}+0.5 \% \mathrm{MgSO}_{4}+0.5 \% \mathrm{~K}_{2} \mathrm{SO}_{4} \mathrm{FS}$ & 73.8 & 93.7 & 70.8 & 23.7 \\
\hline $0.1 \%$ Boric acid $+0.2 \% \mathrm{ZnSO}_{4}+0.5 \% \mathrm{FeSO}_{4+} 1 \% \mathrm{DAP}+1 \% \mathrm{Urea}+0.5 \% \mathrm{~K}_{2} \mathrm{SO}_{4} \mathrm{FS}$ & 76.9 & 95.9 & 74.6 & 24.9 \\
\hline $0.1 \%$ Boric acid $+0.2 \% \mathrm{ZnSO}_{4}+0.5 \% \mathrm{FeSO}_{4}+0.5 \% \mathrm{CaNO}_{3}+0.5 \% \mathrm{MgSO}_{4}+0.5 \% \mathrm{~K}_{2} \mathrm{SO}_{4} \mathrm{FS}$ & 80.1 & 97.1 & 76.1 & 25.1 \\
\hline $25 \mathrm{~kg} \mathrm{ZnSO}_{4}+50 \mathrm{~kg} \mathrm{FeSO}_{4}+10 \mathrm{~kg}$ borax $+0.1 \%$ Boric acid $+0.2 \% \mathrm{ZnSO}_{4}+0.5 \% \mathrm{FeSO}_{4} \mathrm{FS}$ & 83.2 & 98.8 & 80.6 & 25.6 \\
\hline $25 \mathrm{~kg} \mathrm{ZnSO}_{4}+50 \mathrm{~kg} \mathrm{FeSO}_{4}+10 \mathrm{~kg}$ borax $+0.5 \% \mathrm{CaNO}_{3}+0.5 \% \mathrm{MgSO}_{4}+0.5 \% \mathrm{~K}_{2} \mathrm{SO}_{4} \mathrm{FS}$ & 86.8 & 101 & 84.5 & 28.9 \\
\hline SEd & 1.52 & 1.31 & 0.99 & 1.33 \\
\hline $\mathrm{CD}(\mathrm{P}=0.05)$ & 3.15 & 3.76 & 2.09 & 2.81 \\
\hline
\end{tabular}

*FS - Foliar spray during flowering and early berry formation stage; * RDF is common to all the treatments

Foliar spray of micronutrients was advantageous over soil application, because of rapid response, effectiveness, and elimination of deficiency symptoms. Application of micronutrients through foliage spray could be from 10 to 20 times as efficient as soil application (Kuepper, 2003, El-Sheikh et al., 2007; Swathi et al., 2019). Increased fruit set relevant the important role of Boron in pollen germination and pollen tube growth might have increased the berries per bunch, berry size and thereby increase in yield of the crop. Improvement in grape yield and certain quality attributes in response to the foliar spray of boron has also been reported by Rana \& Sharma (1979); Saeed Tadayon (2019).

\subsection{Micronutrients concentration}

The micronutrient contents in petiole and fruits were analyzed at harvest and reported in table 5. Combined soil and foliar application of micronutrients $\left(25 \mathrm{~kg} \mathrm{ZnSO}+50 \mathrm{~kg} \mathrm{FeSO}_{4}+10 \mathrm{~kg}\right.$ borax $+0.5 \%$ $\mathrm{CaNO}_{3}+0.5 \% \quad \mathrm{MgSO}_{4}+0.5 \% \quad \mathrm{~K}_{2} \mathrm{SO}_{4}$ ) recorded the highest concentration of all the micronutrients in the petiole and fruits when compared to NPK control. The Fe content ranged from 84.2 to 101.4 $\mathrm{mg} \mathrm{kg}$ and 66.5 to $78.9 \mathrm{mg} \mathrm{kg}^{-1}$ in petiole and berry respectively. Concerning other micronutrients, the values ranged from 66.8 to $84.5,71.1$ to 86.8 , and 21.1 to $28.9 \mathrm{mg} \mathrm{kg}^{-1}$ for $\mathrm{Mn}, \mathrm{Zn}$, and $\mathrm{Cu}$ respectively in petiole while this value was reported from 23.5 to $35.6,28.7$ to 62.0 and 9.23 to $12.4 \mathrm{mg} \mathrm{kg}^{-1}$ respectively for fruit. Though combined application of RDF + micronutrients as basal and foliar spray $\left(25 \mathrm{~kg} \mathrm{ZnSO}+50 \mathrm{~kg} \quad \mathrm{FeSO}_{4}+10 \mathrm{~kg}\right.$ borax $+0.5 \%$ $\mathrm{CaNO}_{3}+0.5 \% \mathrm{MgSO}_{4}+0.5 \% \mathrm{~K}_{2} \mathrm{SO}_{4}$ ) recorded higher micronutrient concentration in petiole and fruits, and it was at par with $\mathrm{RDF}+25$ $\mathrm{kg} \mathrm{ZnSO}+50 \mathrm{~kg} \mathrm{FeSO}_{4}+10 \mathrm{~kg}$ borax as soil application along with the foliar spraying of $0.5 \% \mathrm{CaNO}_{3}+0.5 \% \mathrm{MgSO}_{4}+0.5 \% \mathrm{~K}_{2} \mathrm{SO}_{4}$ at flowering and early berry forming stages (Table 5) .

The lowest micronutrient content in petiole and fruits was recorded in the NPK control. This indicated that combined application of soil and foliar application of micronutrients $\left(25 \mathrm{~kg} \mathrm{ZnSO}_{4}+50 \mathrm{~kg}\right.$ $\mathrm{FeSO}_{4}+10 \mathrm{~kg}$ borax $+0.5 \% \quad \mathrm{CaNO}_{3}+0.5 \% \quad \mathrm{MgSO}_{4}+0.5 \% \quad \mathrm{~K}_{2} \mathrm{SO}_{4}$ ) not only increased the berry yield but also considerably increased the concentrations of $\mathrm{Fe}, \mathrm{Zn}, \mathrm{Mn}, \mathrm{Cu}$ and $\mathrm{B}$ in both petiole and berry fruit (Table 5). Foliar application of micronutrients had been associated with improved absorption of nutrients, increased number of clusters, average cluster weight, juice content, and quality of vine (Akbar et al., 2013). Foliar application of micronutrients was advantageous over soil application, it might be because of rapid response, effectiveness, and amelioration of deficiency (Kuepper, 2003; El-Sheikh et al 2007).

\subsection{Post-harvest soil nutrient availability}

The post-harvest soil available micronutrients status (Table 6) showed that the application of either soil or combined soil + foliar application of micronutrients increased the micronutrient availability in soil and sustained all micronutrients. However foliar spraying of micronutrients was not sufficient to increase the micronutrient availability in soil and it ranged from 5.54 to $7.24 \mathrm{mg} \mathrm{kg}^{-1}$ for Fe, 2.06 to $4.56 \mathrm{mg} \mathrm{kg}^{-1}$ for $\mathrm{Mn}$, 1.00 to $1.78 \mathrm{mg} \mathrm{kg}^{-1}$ for $\mathrm{Zn}$ and $\mathrm{Cu}$, it ranged from 3.29 to $4.64 \mathrm{mg} \mathrm{kg}^{-}$ 1. Micronutrients availability in post-harvest soils of vine orchard showed sufficient status of all the micronutrients in the soil. This may be attributed to the mineralogy of the soil, organic manuring, and balanced application of all essential nutrients. 
Table 6 Effect of Effect of multi- nutrients application on the post- harvest micronutrients status in the soil $\left(\mathrm{mg} \mathrm{kg}^{-1}\right)$

\begin{tabular}{|c|c|c|c|c|}
\hline \multirow{2}{*}{ Treatment details } & \multicolumn{4}{|c|}{ DTPA Micronutrients $\left(\mathrm{mg} \mathrm{kg}^{-1}\right)$} \\
\hline & $\mathrm{Zn}$ & $\mathrm{Fe}$ & $\mathrm{Mn}$ & $\mathrm{Cu}$ \\
\hline Recommended NPK(RDF) & 1.00 & 5.54 & 2.06 & 3.59 \\
\hline $25 \mathrm{~kg} \mathrm{ZnSO}_{4}+50 \mathrm{~kg} \mathrm{FeSO}_{4}+10 \mathrm{~kg}$ borax & 1.78 & 6.90 & 3.04 & 4.54 \\
\hline $0.1 \%$ Boric acid $+0.2 \% \mathrm{ZnSO}_{4}+1.0 \%$ Urea FS & 1.08 & 5.67 & 2.33 & 4.64 \\
\hline $0.1 \%$ Boric acid $+0.2 \% \mathrm{ZnSO}_{4}+0.5 \% \mathrm{FeSO}_{4} \mathrm{FS}$ & 1.60 & 5.61 & 2.18 & 3.81 \\
\hline $1 \% \mathrm{DAP}+1 \%$ Urea $+0.5 \% \mathrm{~K}_{2} \mathrm{SO}_{4} \mathrm{FS}$ & 1.09 & 5.78 & 2.73 & 4.21 \\
\hline $0.5 \% \mathrm{CaNO}_{3}+0.5 \% \mathrm{MgSO}_{4}+0.5 \% \mathrm{~K}_{2} \mathrm{SO}_{4} \mathrm{FS}$ & 1.12 & 5.94 & 2.84 & 4.11 \\
\hline $0.1 \%$ Boric acid $+0.2 \% \mathrm{ZnSO}_{4}+0.5 \% \mathrm{FeSO}_{4+} 1 \% \mathrm{DAP}+1 \%$ Urea $+0.5 \% \mathrm{~K}_{2} \mathrm{SO}_{4} \mathrm{FS}$ & 1.33 & 6.44 & 3.42 & 3.95 \\
\hline $0.1 \%$ Boric acid $+0.2 \% \mathrm{ZnSO}_{4}+0.5 \% \mathrm{FeSO}_{4}+0.5 \% \mathrm{CaNO}_{3}+0.5 \% \mathrm{MgSO}_{4}+0.5 \% \mathrm{~K}_{2} \mathrm{SO}_{4} \mathrm{FS}$ & 1.19 & 6.49 & 3.99 & 4.82 \\
\hline $25 \mathrm{~kg} \mathrm{ZnSO}_{4}+50 \mathrm{~kg} \mathrm{FeSO}_{4}+10 \mathrm{~kg}$ borax $+0.1 \%$ Boric acid $+0.2 \% \mathrm{ZnSO}_{4}+0.5 \% \mathrm{FeSO}_{4} \mathrm{FS}$ & 2.43 & 6.68 & 3.55 & 5.29 \\
\hline $25 \mathrm{~kg} \mathrm{ZnSO}_{4}+50 \mathrm{~kg} \mathrm{FeSO}_{4}+10 \mathrm{~kg}$ borax $+0.5 \% \mathrm{CaNO}_{3}+0.5 \% \mathrm{MgSO}_{4}+0.5 \% \mathrm{~K}_{2} \mathrm{SO}_{4} \mathrm{FS}$ & 2.61 & 7.24 & 4.56 & 6.31 \\
\hline SEd & 1.33 & 0.94 & 1.52 & 1.03 \\
\hline $\mathrm{CD}(\mathrm{P}=0.05)$ & 2.83 & 1.97 & 3.19 & 2.16 \\
\hline
\end{tabular}

*FS - Foliar spray during flowering and early berry formation stage

* RDF is common to all the treatments

The variations in concentrations of DTPA micronutrients could be attributed to the nature and behavior of the elements in the soil itself. The use of organic manures and micronutrient fertilizer might have contributed to micronutrient availability. Combined application of soil + foliar spraying of micronutrients, sustained the availability in soil when compared to NPK control. Many of the grape soils shared higher availability of DTPA Mn and $\mathrm{Zn}$ while, DTPA $\mathrm{Cu}$ and Fe were observed in medium and higher ranges ( Kondi et al., 2018).

\section{Conclusion}

Nutrient management, water, and vineyard maintenance play a major role in sustained yield and soil fertility in a continuous cycle system of grape cultivation. To assess the effect of the integrated supply of major, secondary, and micronutrients application through the soil and foliar spray on various growth, yield, and quality attributes, a current field experiment was conducted at 8 years old orchard of panneer variety during the summer season of 2017 at Theethipalayam village of Coimbatore district. The effect of soil and foliar application of secondary and micronutrients showed that foliar spraying of secondary nutrients $(\mathrm{Ca}, \mathrm{Mg})$ and micronutrients $(\mathrm{Zn}, \mathrm{Fe}$, B) along with basal recommended NPK increased the yield and yield attributes of grapes. Basal application of 100\% RDF (200:160:1200 $\mathrm{g} /$ vine in two splits) $+25 \mathrm{~kg} \mathrm{ZnSO}_{4}+50 \mathrm{~kg} \mathrm{FeSO}_{4}+10 \mathrm{~kg}$ borax along with foliar spraying of $0.5 \% \mathrm{CaNO}_{3}+0.5 \% \mathrm{MgSO}_{4}+0.5 \% \mathrm{~K}_{2} \mathrm{SO}_{4}$ registered higher fruit yield and bunch weight. Further, higher juice content and TSS was also recorded with the combined soil application of RDF (200: 160:1200 g/vine in two splits) $+25 \mathrm{~kg}$
$\mathrm{ZnSO}_{4}+50 \mathrm{~kg} \mathrm{FeSO}_{4}+10 \mathrm{~kg}$ borax along with foliar spraying of $0.5 \%$ $\mathrm{CaNO}_{3}+0.5 \% \mathrm{MgSO}_{4}+0.5 \% \mathrm{~K}_{2} \mathrm{SO}_{4}$ twice during flowering and early berry formation stage.

From the above experiment, it can be concluded that soil and foliar application of multi-nutrients have a stimulatory effect on the various yield and quality parameters of grape, this showed that basal application of 100\% RDF (200:160:1200 NPK g/vine in two splits) $+25 \mathrm{~kg} \mathrm{ZnSO}_{4}+50 \mathrm{~kg} \mathrm{FeSO}_{4}+10 \mathrm{~kg}$ borax along with foliar spraying of $0.5 \% \mathrm{CaNO}_{3}+0.5 \% \mathrm{MgSO}_{4}+0.5 \% \mathrm{~K}_{2} \mathrm{SO}_{4}$ was found effective in increasing the grape yield and quality.

\section{Acknowledgment}

The authors greatly acknowledge the financial support rendered by the AICRP Micronutrients, Indian Society of Soil Science, Bhopal, and Tamil Nadu Agricultural University, Coimbatore for the manpower and facility support to complete the research project.

\section{Conflict of interest}

The authors declare that they have no conflict of interest

\section{References}

Abo-Ahmedeh H, Mhasneh A, Rawashdeh H (2020) Using Soil and Foliar Applications of some Fertilizers to Improve the Yield and Quality Parameters of Table Grapes (Vitis vinifera L.). $\begin{array}{lllll}\text { Bulletin UASVM Series Agriculture (77)1 } / 2020 & \text {. }\end{array}$ DOI:10.15835/buasvmen-agr: 2019.0016. 
Akbar S, Vahid M, Ahmad TP, Abdolreza A (2013) Effect of Zn, $\mathrm{Cu}$ and $\mathrm{Fe}$ foliar application on fruit set and some quality and quantity characteristics of pistachio trees South Western. Journal of Horticulture, Biology and Environment 4(1): 19-34.

Ashley R (2011) Grapevine Nutrition-An Australian Perspective, Foster's Wine Estates Americas, available at http://ucanr.org/sites/nm/files/76731.pdf access on 29April, 2020.

Bhat ZA, Padder SA, Cunaie AQ, Dar NA (2017) Soil Fertility Status of Grape (Vitis vinifera L) orchard soils, A review. International Journal of Pure and Applied Bioscience 5 (2): 892-900.

Ebadi A, Atashkar D, Babalar M (2001) Effect of boron on pollination and fertilization in seedless grapevine cvs White Seedless and Askari. Iranian Journal agriculture Sciences 32 (2): 457-465.

El-Sheikh MH, Khafgy SAA, Zaied SS (2007) Effect of Foliar Application with Some Micronutrients on Leaf Mineral Content, Yield and Fruit Quality of "Florida Prince Desert Red" Peach Trees. Journal of Agricultural and Biological Science 3: 309-315.

Bilir H, Exbic, Gokdemir N, Erdem H (2018) Effects of Boron on yield, quality and leaf nutrients of Isabella (Vitis labrusca L) Grape cultivar. Acta Scientiarum Polonorum Hortorum Cultus 17(1): 149-157.

Jackson ML (2005) Soil chemical analysis: Advanced course: UWMadison Libraries Parallel Press.

Kondi AE, Prashant Champa CT, Bhadravathi V, Nagarajan MS (2018) Secondary and micronutrients status in soils of vine and table grape orchards of northen Karnataka. International Journal of Chemical Studies 6(3): 2335-2338.

Kuepper G (2003) Foliar fertilization, The National Sustainable Agriculture Information Service. Available on www.attra.ncat.org access on $29^{\text {th }}$ April, 2020.

Lindsay WL, Norvell WA (1978) Development of a DTPA soil test for $\mathrm{Zn}, \mathrm{Fe}, \mathrm{Mn}$ and $\mathrm{Cu}$. Journal of American Soil Science Society 42:421-428.
Saeed Tadayon M, Moafpaurian G (2019) Effects of Exogenous epi-brassinolid, zinc and boron foliar nutrition on fruit development and ripening of grape (Vitis vinifera L. clv. 'Khalili'). Scientia Horticulturae 24:94-101.

Olsen SR, Cole CV, Watanabe FS, Dean AL (1954) Estimation of available phosphorous in soils by extraction with sodium bicarbonate (USDA) Circular No. 939.

Panse VG, Sukhatme PV (1967) Statistical methods for agricultural workers, ICAR Publications, New Delhi.

Piper AM (1944) A graphic procedure in the geochemical interpretation of water-analyses. Eos, Transactions American Geophysical Union 25(6): 914-928.

Rana RS, Sharma HC (1979) Effect of iron sprays on growth, yield and quality of grapes. Punjab Horticulture Journal 19 (1-2): 31-34.

Ranganna S (1997) Hand Book of analysis and quality control for fruits and vegetables products. 3, edition, Tata McGraw - Hill publishing company Ltd. New Delhi, 12-16.

Souri MK, Hatamian M (2019) Aminochelates in plant nutrition: a review. Journal of Plant Nutrition 42 (1): 67-78.

Stanford G, English L (1949) Use of the flame photometer in rapid soil tests for K and Ca. Agronomy Journal 41 (9): 446-447.

Subbiah B, Asija G (1956) Alkaline permanganate method of available nitrogen determination. Current Science 25: 259.

Swathi AS, Jegadeeswari D, Chitdeshwari T, Kavitha S (2019) Effect of foliar nutrition of calcium and boron on the yield and quality attributes of grape. Journal of Pharmacognosy and Phtochemistry 8(3): 3625-3629.

Walkley A, Black IA (1934) An examination of the Degtjareff method for determining soil organic matter, and a proposed modification of the chromic acid titration method. Soil science 37 (1): 29-38. 